\title{
Intrinsic Value A Base to Pick Scrip
}

\author{
M Haritha ${ }^{1}$, Ravi $\mathrm{V}^{2}$, Dr. O Ravisankar ${ }^{3}$ \\ ${ }^{I}$ (Department of MBA, RR Institute of Advanced Studies, India) \\ ${ }_{2}^{2}$ (Department of Management Studies, Acharya Institute of Management and Science, India) \\ ${ }^{3}$ (Department of MBA, Sathya Institute of Management Studies, India)
}

\begin{abstract}
Investment means sacrificing some money value in the present with the expectation of making gains in the future. Every investor is interested in knowing the appropriate timing for investment, as well as the best avenue for investment. For investing the surplus money, the investor should be willing to pay the certain value for the stock. To know about the real value of the stock is not easy for the investor. At a same time, it is not so easy to find out the real worth for the company stock. Certain analysis can be used to select the stock for investment, like Fundamental analysis and Technical analysis. Thus, this research work is done for facilitating the investor to know about the worth able value of the stock for investment. This research paper is aims to arrive at the intrinsic value of shares.

Keywords: Dividend per share, D/P ratio, Price Earning ratio, Intrinsic value, Fundamental Analysis
\end{abstract}

\section{Introduction:}

Fundamental analysis is a stock valuation method that uses financial and economic analysis to predict the movement of stock prices. The fundamental information that is analyzes can include a company's financial reports, and non-financial information such as estimates of the growth of demand for products sold by the company, industry comparisons, and economy-wide changes, changes in government policies etc.. The market price of a stock tends to move towards its real value or intrinsic value.

\section{INTRINSIC VALUE:}

Intrinsic value refers to the value of a security which is intrinsic to or contained in the security itself. It is also frequently called fundamental value. The intrinsic value helps in making investment decisions. The comparison of intrinsic value and prevailing market price can help the investor to deciding about the stock to be purchased or sold. If the intrinsic value of a stock is above the current market price, the investor would purchase the stock because investor knows that the stock price would rise and move towards its intrinsic value. If the intrinsic value of a stock was below the market price, the investor would sell the stock because investor knows that the stock price is going to fall and come closer to its intrinsic value.

\section{DIVIDEND PER SHARE:}

The sum of declared dividends for every ordinary share issued. Dividend per share (DPS) is the total dividends paid out over an entire year (including interim dividends but not including special dividends) divided by the number of outstanding ordinary shares issued. Dividends are a form of profit distribution to the shareholder. Having a growing dividend per share can be a sign that the company's management believes that the growth can be sustained.

\section{EARNING PER SHARE:}

Earnings per share (EPS) is the amount of earnings per each outstanding share of a company's stock. Investor can able to analyze how the underlying company has performed in the past, how it is doing at present how it is likely expected to perform in the future. This leads the investment analyst to estimate the future expected earnings per share of the stock.

\section{DIVIDEND PAY OUT RATIO:}

The percentage of earnings paid to shareholders in dividends. The payout ratio provides an idea of how well earnings support the dividend payments. More mature companies tend to have a higher payout ratio.

\section{DIVIDEND GROWTH RATE:}

The annualized percentage rate of growth that a particular stock's dividend undergoes over a period of time. The time period included in the analysis can be of any interval desired, and is calculated by using the least squares method, or by simply taking a simple annualized figure over the time period. The dividend growth rate is necessary in order to use the dividend discount model, which is a security pricing model that assumes that a stock's price is determined by the estimated future dividends, discounted by the excess of internal growth over 
the firm's estimated dividend growth rate. A history of strong dividend growth could mean that future dividend growth is likely, which can signal long-term profitability for a given company.

\section{RETURN ON EQUITY}

The amount of net income returned as a percentage of shareholders equity. Return on equity measures a corporation's profitability by revealing how much profit a company generates with the money shareholders have invested.

\section{PRICE-TO-EARNINGS RATIO:}

The price to earnings ratio of a stock is a measure of the price paid for a share relative to the annual net income or profit earned by the firm per share. Price to earnings ratio can be calculated by dividing the company's market capitalization by its total annual earning. Price to earning ration is commonly called as P/E ratio.

\section{NEED OF THE PAPER:}

Surplus income will motivate the individual to invest. Investment avenues were change from bank deposits, Gold investment, and real estate etc. Now a day's, a wide variety of investment avenues are open to the investment to suit their needs and nature. At present, investors are interested to invest in stock market. Investing in the stock market, they should know about, how to select the stock. The research is based on investor can able to select the stock by the way of its intrinsic value. For facilitating the investor this research paper is aimed towards to determine the worth able value of the stock for initial investment.

\section{STATEMENT OF THE PROBLEM:}

The fundamental analysis used for investor to select stock in the initial period of investment, this becoming the challenge to the investor, for selecting the right stock. Thus the research is about how to select the stock from the market by using its intrinsic value.

\section{OBJECTIVES OF THE STUDY:}

1. To estimate the dividend pay out ratio and retention ratio.

2. To estimate the long term growth rate in equity and projected EPS of the stocks.

3. To find the intrinsic value of stocks.

4. To compare the intrinsic value with the market value of stocks.

5. To suggest the investor for selecting the stock in the market.

\section{SCOPE OF THE STUDY:}

This research covers about 10 company stocks only. Analysis will be done for the five years. The company stocks are as follows:

\begin{tabular}{|c|l|l|l|}
\hline \multicolumn{1}{|l|}{ S.No } & Company Name & Industry & Symbol \\
\hline 1. & Bharat Heavy Electricals Ltd. & Electrical equipment & BHEL \\
\hline 2. & Hero Honda Motors Ltd. & $\begin{array}{l}\text { Automobiles }-2 \text { and } 3 \\
\text { wheelers }\end{array}$ & HEROHONDA \\
\hline 3. & Hindustan Unilever Ltd. & Diversified & HINDUNILVR \\
\hline 4. & ICICI Bank Ltd. & Banks & ICICIBANK \\
\hline 5. & Infosys Technologies Ltd. & Computers - software & INFOSYSTCH \\
\hline 6. & Maruti Suzuki India Ltd. & Automobiles - 4 wheelers & MARUTI \\
\hline 7. & ONGC Ltd. & Oil exploration & ONGC \\
\hline 8. & Reliance Industries Ltd. & Refineries & RELIANCE \\
\hline 9. & State Bank of India & Banks & SBIN \\
\hline 10. & Tata Steel Ltd. & Steel and steel products & TATASTEEL \\
\hline & & &
\end{tabular}

\section{Research Methodology:}

The main purpose of the research is to give guidelines to the investor for selecting the stock. Secondary data only used for the purpose of the study. The secondary data for this study are collected from newspaper, books, magazines, the internet, and other documents.

Plan of Analysis: The data collected will be edited, classified, tabulated and Statistical tools like Average, Tables and other research tools are used to analyze the data.

Period of the Study: $1^{\text {st }}$ April 2006 to $31^{\text {st }}$ March 2011.

Formula used: 
Dividend Pay out Ratio (DPOR)

Average DPOR for 5 years

Average Retention Ratio

Average return on equity

Long term growth rate in equity $(\mathrm{g})$

Normalized Average price Earnings Ratio

Projected EPS for current year

Intrinsic Value

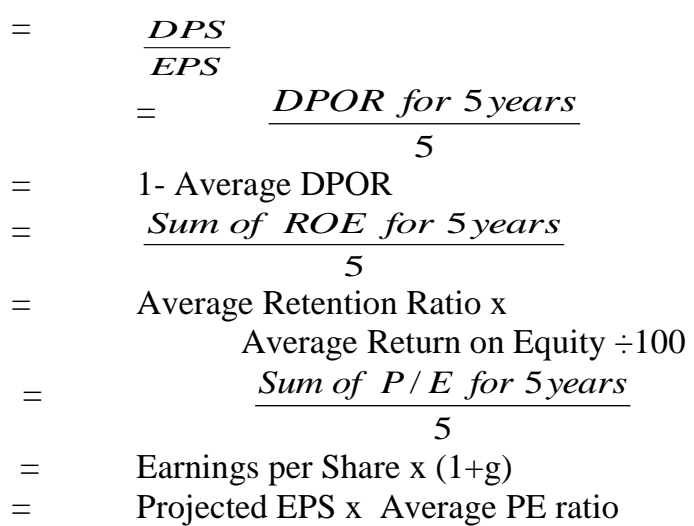

\section{LIMITATIONS:}

$>$ This research is based on the company analysis only

$>$ This research is done for 10 company's stocks.

$>$ The period of the study from $1^{\text {st }}$ April 2006 to $31^{\text {st }}$ March 2011.

$>$ The future is always uncertain; the result reflects the values of that period.

ANALYSIS:

Table - 1: Dividend pay out ratio is calculated by taking 10 top NSE companies EPS and DPS for 5years as fallows

\begin{tabular}{|c|c|c|c|}
\hline S.No & Company Stock & Ave D/E ratio & Ave Retention \\
\hline 1 & BHEL & 0.246405 & 0.753595 \\
\hline 2 & HEROMOTOCORP & 0.634244 & 0.365756 \\
\hline 3 & HINDUNILVR & 0.728105 & 0.271895 \\
\hline 4 & ICICIBANK & 0.310967 & 0.689033 \\
\hline 5 & INFOSYSTCH & 0.322428 & 0.677572 \\
\hline 6 & MARUTI & 0.08243 & 0.91757 \\
\hline 7 & ONGC & 0.487247 & 0.512753 \\
\hline 8 & RELIANCE & 0.127726 & 0.872274 \\
\hline 9 & SBIN & 0.200832 & 0.799168 \\
\hline 10 & TATASTEEL & 0.199155 & 0.800845 \\
\hline
\end{tabular}

It has been observed that, HUL and Hero Moto Corp are paying very well to their investors from their earnings and retain very less money. Maruti has been retain $90 \%$ of their income and Reliance and SBIN also paying very less to the investors and retains more earnings.

Table - 2: Long term growth of the companies has been calculated by using Average ROE of the companies and Average retention as fallows

\begin{tabular}{|l|l|l|l|l|}
\hline S.No & Company Stock & Average ROE & Ave Retention & Long term growth g \\
\hline 1 & BHEL & 29.786 & 0.753595 & 0.2244658 \\
\hline 2 & HEROHONDA & 46.606 & 0.365756 & 0.1704642 \\
\hline 3 & 92.408 & 0.271895 & 0.2512527 \\
\hline 4 & HINDUNILVR & 10.114 & 0.689033 & 0.0696888 \\
\hline 5 & ICICIBANK & 34.43 & 0.677572 & 0.233288 \\
\hline 6 & INFOSYSTCH & 20.632 & 0.91757 & 0.189313 \\
\hline 7 & MARUTI & 23.094 & 0.512753 & 0.1184152 \\
\hline 8 & ONGC & 18.84 & 0.872274 & 0.1643364 \\
\hline 9 & RELIANCE & 15.326 & 0.799168 & 0.1224805 \\
\hline 10 & SBIN & 23.614 & 0.800845 & 0.1891115 \\
\hline
\end{tabular}

From table - 2, HUL has shown very good return on equity with compare to other companies and showing $25 \%$ strong growth rate also. Hero Moto Corp also has shown good return on equity but growth rate is average at $17 \%$. Among all ten companies, ICICI returns are less and growth rate also very less. 
Table - 3 Projected EPS is calculated, by taking 5years average EPS and growth rate as fallows

\begin{tabular}{|l|l|l|l|l|l|}
\hline S.No & Company Stock & Avg EPS & $\mathbf{g}$ & $\mathbf{1 + g}$ & Proj EPS \\
\hline 1 & BHEL & 86.408 & 0.2244658 & 1.224466 & 105.8036 \\
\hline 2 & HEROHONDA & 72.782 & 0.1704642 & 1.170464 & 85.18873 \\
\hline 3 & HINDUNILVR & 9.892 & 0.2512527 & 1.251253 & 12.37739 \\
\hline 4 & ICICIBANK & 37.306 & 0.0696888 & 1.069689 & 39.90581 \\
\hline 5 & INFOSYSTCH & 91.874 & 0.233288 & 1.233288 & 113.3071 \\
\hline 6 & MARUTI & 64.546 & 0.189313 & 1.189313 & 76.7654 \\
\hline 7 & ONGC & 65.428 & 0.1184152 & 1.118415 & 73.17567 \\
\hline 8 & RELIANCE & 84.61 & 0.1643364 & 1.164336 & 98.5145 \\
\hline 9 & SBIN & 122.208 & 0.1224805 & 1.122481 & 137.1761 \\
\hline 10 & TATASTEEL & 67.292 & 0.1891115 & 1.189112 & 80.01769 \\
\hline
\end{tabular}

SBIN, Infosys, and BHEL are having high projected EPS and it going to indicate that these companies are going to have higher intrinsic values and HUL is having very less projected EPS it mean that this is going to have less intrinsic value.

Table - 4 Intrinsic values are calculated by taking 5years average P/E ratio and projected EPS

\begin{tabular}{|l|l|l|l|l|}
\hline S.No & Company Stock & Proj EPS & Avg P/E & Intrinsic Value \\
\hline 1 & BHEL & 105.8036 & 24.9057 & 2635.113 \\
\hline 2 & HEROHONDA & 85.18873 & 17.45442 & 1486.92 \\
\hline 3 & HINDUNILVR & 12.37739 & 24.35216 & 301.4162 \\
\hline 4 & ICICIBANK & 39.90581 & 22.24991 & 887.9007 \\
\hline 5 & INFOSYSTCH & 113.3071 & 23.5152 & 2664.439 \\
\hline 6 & MARUTI & 76.7654 & 15.57739 & 1195.805 \\
\hline 7 & ONGC & 73.17567 & 21.19156 & 1550.707 \\
\hline 8 & RELIANCE & 98.5145 & 23.09613 & 2275.304 \\
\hline 9 & SBIN & 137.1761 & 14.23635 & 1952.887 \\
\hline 10 & TATASTEEL & 80.01769 & 8.927468 & 714.3554 \\
\hline
\end{tabular}

It has been observed that 5years average P/E of all companies is 15 to 25 except Tata steel. Tata steel average $\mathrm{P} / \mathrm{E}$ is at 8.9. Calculated intrinsic values of BHEL, Infosys, Reliance and SBIN are in higher stage and HUL intrinsic value is lower stage, it mean that stocks are not going choose by higher or lower intrinsic values and going to choose by comparing intrinsic valves with concern company market value.

Table - 5; comparison of intrinsic values with market values from April 2010 to Sep 2010

\begin{tabular}{|l|l|l|l|l|l|l|l|l|}
\hline S.No & Company Stock & April'10 & May'10 & June'10 & July'10 & Aug'10 & Sep'10 & $\begin{array}{l}\text { Intrinsic } \\
\text { Value }\end{array}$ \\
\hline 1 & BHEL & 2000.60 & 1943.15 & 2050.55 & 1839.60 & 1768.35 & 1639.65 & 2635.113 \\
\hline 2 & HEROHONDA & 1710.00 & 1854.75 & 1877.20 & 1785.10 & 2051.75 & 1941.75 & 1486.92 \\
\hline 3 & HINDUNILVR & 285.20 & 304.55 & 343.65 & 324.00 & 320.40 & 340.60 & 301.4162 \\
\hline 4 & ICICIBANK & 1114.45 & 1086.10 & 1094.65 & 1036.75 & 873.25 & 875.40 & 887.9007 \\
\hline 5 & INFOSYSTCH & 2906.25 & 2785.65 & 2910.45 & 2775.90 & 2342.95 & 2533.05 & 2664.439 \\
\hline 6 & MARUTI & 1317.65 & 1230.15 & 1159.90 & 1206.65 & 1091.55 & 1083.00 & 1195.805 \\
\hline 7 & ONGC & 307.80 & 281.05 & 274.25 & 269.25 & 263.30 & 266.10 & 1550.707 \\
\hline 8 & RELIANCE & 983.75 & 951.85 & 898.50 & 827.95 & 782.60 & 808.35 & 2275.304 \\
\hline 9 & SBIN & 2804.60 & 2297.95 & 2404.65 & 2344.80 & 1973.80 & 1911.05 & 1952.887 \\
\hline 10 & TATASTEEL & 616.50 & 589.00 & 610.25 & 564.00 & 468.55 & 415.35 & 714.3554 \\
\hline
\end{tabular}

\section{Conclusion:}

Every investor will look ahead to be with the triumphant scripts which can give better income. Liberal methods are accessible for selecting the stock with respect to risk and returns. Intrinsic value analysis will also supportive to look at the stock performance and choosing the stock. Especially the investment seeker can choose intrinsic value as a base for analyzing the stock. 
References:

[1]. www.Investopedia.com

[2]. www.nse-india.com

[3]. www.indiabulls.com

[4]. www.livemint.com

[5]. Investment Analysis \& Portfolio Management, 4th Edition, 2008, Prasanna Chandra, Himalaya Publishers. 